\title{
Sistem Pendukung Keputusan Pengalokasian Spare Part
}

\author{
Rita Wiryasaputra*1 ${ }^{1}$ dan Sri Hartati ${ }^{2}$ \\ ${ }^{1}$ Mahasiswa Program Pascasarjana Ilmu Komputer, FMIPA, Universitas Gadjah Mada, \\ Yogyakarta. \\ ${ }^{2}$ Staf pengajar Program Pascasarjana Ilmu Komputer, FMIPA, Universitas Gadjah Mada, \\ Yogyakarta. \\ e-mail: *11ritasaputra@gmail.com, ${ }^{2}$ shartati@ugm.ac.id
}

\begin{abstract}
Abstrak
Era informasi yang semakin berkembang mempengaruhi lingkungan bisnis. Pengaruhnya dapat dilihat pada proses pengambilan keputusan. Proses pengambilan keputusan terhadap sejumlah alternatif dan sejumlah tujuan diselesaikan dengan sebuah sistem. Sistem yang bermodelkan Multi Attribute Decision Making (MADM) dan Multi Objective Decision Making (MODM). Model MODM digunakan untuk menyelesaikan perancangan alternatif terbaik dan model MADM digunakan untuk menyelesaikan penyeleksian terhadap beberapa alternatif dalamjumlah yang terbatas. Salah satu pendekatan model MADM adalah TOPSIS (Technique for Order Preference by Similarity to Ideal Solution). Konsep utama TOPSIS adalah alternatif preferensi terbaik memiliki jarak terpendek dari solusi ideal positif dan memiliki jarak terjauh dari solusi ideal negatif. Hasil metode TOPSIS adalah perankingan terhadap sejumlah alternatif. Salah satu masukan dari metode TOPSIS adalah nilai pembobotan kriteria. Nilai pembobotan kriteria dapat diberikan secara langsung oleh pengambil keputusan atau dihitung melalui sebuah metode. Penelitian akan menghitung nilai pembobotan kriteria dengan metode Entropy. Tujuannya adalah untuk memberikan objektifitas pembobotan kriteria. Penelitian mengangkat kasus tentang pengalokasian spare part ke sejumlah store. Alternatif terbaik dengan sumber daya yang terbatas, beberapa tujuan yang saling bertentangan didekati dengan metode Goal programming. Pengambilan keputusan akan lebih terarah karena sistem menghasilkan perankingan store spare part, dan menampilkan informasi alokasi spare part.
\end{abstract}

Kata kunci-Sistem Pendukung Keputusan, Entropy, TOPSIS, Goal Programming

\begin{abstract}
The capabilities of computrized systems facilitate decision support in a number of ways, such as speed computations, increased productivity, improved data management and others. Decisions are often made by individuals. There may be conflicting objectives even for a decision maker. The conflicting objectives can be solved by goal programming. Research of spare part allocation focuses on an individual decision maker and presents the solving problem with Multiple Criteria Decision Making (MCDM). A lot of MCDM approaches have been developed and applied to diverse fields, like engineering, management, economic, etc. As one of the known classical MCDM approaches, TOPSIS method is known to be a common method to get the preliminary outcome. The main concept of TOPSIS is the best alternative has the shortest distance from the positive ideal solution and has the longest distance from the negative ideal solution. Before the stores are ranked with TOPIS method, the management assigned a weightage to each store using Entropy method.
\end{abstract}

Keywords - Decision Support Model, Entropy, TOPSIS, Goal Programming.

Received February 22 $2^{\text {th }}, 2012 ;$ Revised March 15 $5^{\text {th }}$ 2012; Accepted June $9^{\text {th }}, 2012$ 


\section{PENDAHULUAN}

$\mathrm{M}$ odel pengambilan keputusan merupakan alat yang merepresentasikan permasalahan keputusan sedemikian rupa, sehingga memungkinkan identifikasi dan evaluasi sistematik terhadap ketersediaan semua alternatif keputusan. Model pengambilan keputusan terdiri dari Multi Attribute Decision Making (MADM) dan Multi Objective Decision Making (MODM). Model MODM digunakan untuk menyelesaikan perancangan alternatif terbaik dan model MADM digunakan untuk menyelesaikan penyeleksian terhadap beberapa alternatif dalam jumlah yang terbatas. Sistem berbasis model terdiri dari prosedur-prosedur pemrosesan data dan hasilnya menjadi bahan masukan untuk pengambil keputusan dalam mengambil keputusan. Sistem harus sederhana, mudah dikontrol, mudah beradaptasi, mudah digunakan. Tetapi fungsi dari sistem yang dibangun tersebut bukan untuk menggantikan peran penting dari pengambil keputusan[1]. Pengalokasian spare part merupakan salah satu permasalahan bagi perusahaan yang memiliki sumber daya terbatas dan ingin memaksimalkannya, tapi tetap ingin memberikan pelayanan terhadap pelanggan serta mendapatkan keuntungan. Salah satu pendekatan model MADM yang sederhana, efisien dalam komputasi adalah TOPSIS (Technique For Order Performance By Similarity To Ideal Solution). Konsep utama TOPSIS adalah alternatif preferensi terbaik tidak hanya memiliki jarak terpendek dari solusi ideal positif, tetapi juga memiliki jarak terjauh dari solusi ideal negatif [2]. Proses perankingan store spare part dengan TOPSIS dilakukan untuk menyederhanakan bentuk matematis metode Goal Programming yang digunakan dalam perhitungan kapasitas pendistribusian spare part. Hampir semua metode dan permasalahan MADM memerlukan informasi (bobot kriteria) yang mengacu pada kepentingan relatif dari tiap atribut. Bobot kriteria dapat diberikan oleh pengambil keputusan secara langsung (berdasar subjektifitas atau pengalaman pribadi pengambil keputusan) atau melalui suatu metode. Penelitian ini menggunakan bobot kriteria yang diberikan secara langsung oleh pengambil keputusan. Diskriminasi diantara sekumpulan data bobot kriteria dihitung dengan menggunakan konsep Entropy. Metode Entropy digunakan untuk mengestimasi jumlah data secara kuantitatif dan menghitung secara objektif bobot relatif informasi [3]. Metode Entropy tidak mensyaratkan bahwa satuan maupun range dari tiap kriteria harus sama [4]. Perhitungan bobot kriteria menggunakan model Entropy dilakukan oleh Triyanti dan Gadis [5] . Bedanya dari pembahasan penelitian sebelumnya adalah penelitian yang dilakukan oleh Triyanti, menggunakan model decision Promethee untuk menentukan ranking supplier dalam industri makanan. Beberapa tujuan bisnis yang saling bertentangan dapat direpresentasikan secara model matematis. Model matematis membantu pengambil keputusan dalam menyelesaikan permasalahan, sebelum diimplementasikan langsung ke dunia nyata. Salah satu permodelan matematis adalah goal programming dengan tujuan untuk meminimumkan penyimpangan diantara sekumpulan tujuan dan pemuasan pencapaian usaha sesuai batasan yang telah ditetapkan.

\section{METODE PENELITIAN}

Penelitian mengambil studi kasus tentang alokasi spare part untuk beberapa store.

Input data yang dilakukan meliputi:

1. Data pengguna sistem seperti username, password.

2. Data store yang akan dijadikan alternatif pilihan keputusan, seperti id store, lokasi store, area, telepon, email dan alamat.

3. Data spare part seperti id spare part, deskripsi spare part, jumlah persediaan spare part saat ini $(\mathrm{OH})$, jumlah spare part yang dipesan $(\mathrm{OO})$, batas minimum persediaan, batas maksimum persediaan.

4. Data kriteria yang dijadikan parameter perankingan store, seperti nama kriteria, sifat kriteria, bobot kriteria, range kriteria.

IJCCS Vol. 6, No. 1, January 2012: 11-22 
5. Data transaksi yang dijadikan batasan seperti bobot preferensi, jumlah kebutuhan spare part yang di-request, jumlah store yang akan disusun secara ranking, jumlah budget biaya pengiriman.

Adapun prosedur yang dilakukan adalah:

1. Memberikan penilaian terhadap store spare part sesuai kriteria yang telah ditentukan.

2. Menghitung bobot objektifitas dari kriteria dengan menggunakan metode Entropy.

3. Melakukan perankingan store spare part dengan metode TOPSIS berdasarkan perhitungan nilai dari masing-masing store spare part.

4. Menghitung kapasitas pendistribusian jumlah spare part dengan metode goal programming.

Tahapan proses sistem seperti berikut:

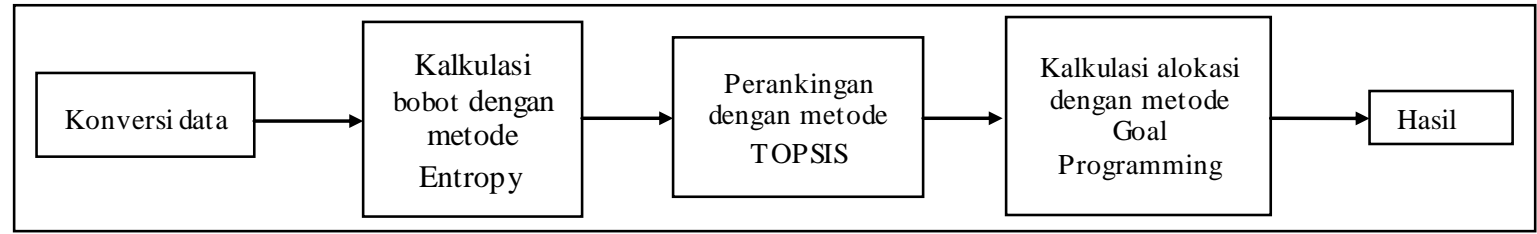

Gambar 1. Tahapan proses sistem

Keluaran sistem meliputi:

1. Hasil perankingan store dengan proses perhitungan metode Entropy-TOPSIS dari nilai tertinggi hingga nilai terendah.

2. Kapasitas distribusi spare part dari masing-masing store

Penelitian ini menggunakan model pendekatan MADM TOPSIS (Technique For Order Performance By Similarity To Ideal Solution) dengan mempertimbangkan data kasus yang berbentuk cardinal. Penelitian menggunakan bobot kriteria yang diberikan secara langsung oleh pengambil keputusan. Diskriminasi diantara sekumpulan data bobot kriteria dihitung dengan menggunakan konsep Entropy.

Tabel 1. Data contoh beberapa store

\begin{tabular}{|l|c|c|c|c|c|}
\hline \multirow{2}{*}{ Alternatif } & \multicolumn{5}{|c|}{ Kriteria } \\
\cline { 2 - 6 } & $\begin{array}{c}\text { Kuantiti spare } \\
\text { part y ang } \\
\text { dimiliki }\end{array}$ & $\begin{array}{c}\text { Lama } \\
\text { pengiriman }\end{array}$ & $\begin{array}{c}\text { Persentase } \\
\text { keluhan } \\
\text { pelanggan }\end{array}$ & $\begin{array}{c}\text { Persentase } \\
\text { keuntungan } \\
\text { store }\end{array}$ & $\begin{array}{c}\text { Tingkat } \\
\text { komunikasi }\end{array}$ \\
\hline Semarang & 24 & 2 & 0 & 10 & sangat baik \\
\hline $\begin{array}{l}\text { Batu Hijau - Nusa } \\
\text { Tenggara Timur- Newmont }\end{array}$ & 14 & 3 & 3 & 30 & $\begin{array}{c}\text { sangat } \\
\text { buruk }\end{array}$ \\
\hline Gunung Bay an-Kaltim & 62 & 1 & 7 & 20 & sangat baik \\
\hline
\end{tabular}

Proses penelitian dimulai dengan mengkonversi data contoh sesuai dengan penilaian manajer terhadap kriteria yang ada. Penilaian manajer terhadap kriteria, ditunjukkan pada tabel 2.

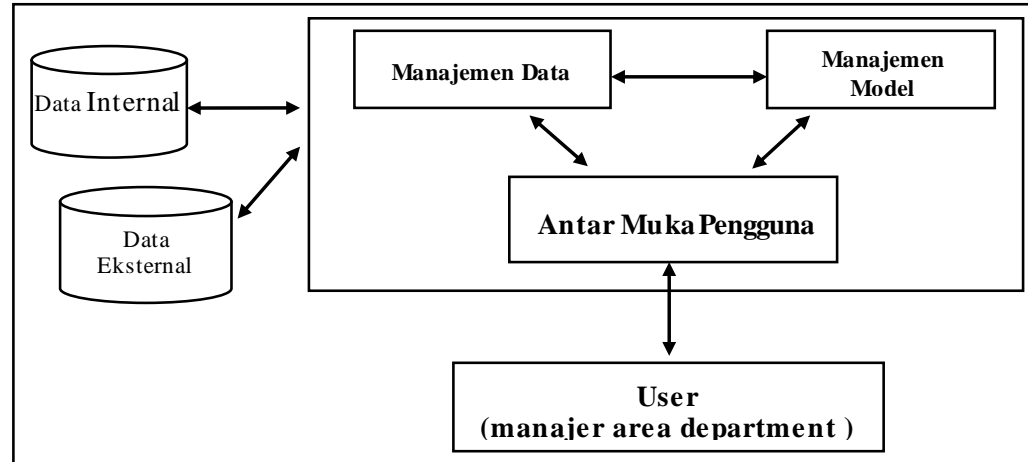

Keterangan:

Data Internal $=$ Data persediaan spare part, data store

Data Eksternal = lama pengiriman Manajemen Model = Entropy, TOPSIS, Goal Programming

Ant ar Muka Pengguna $=$ Web based (HT ML, PHP)

Manajemen Data $=$ MySQL

User = Manajer

Gambar 2. Arsitektur sistem 


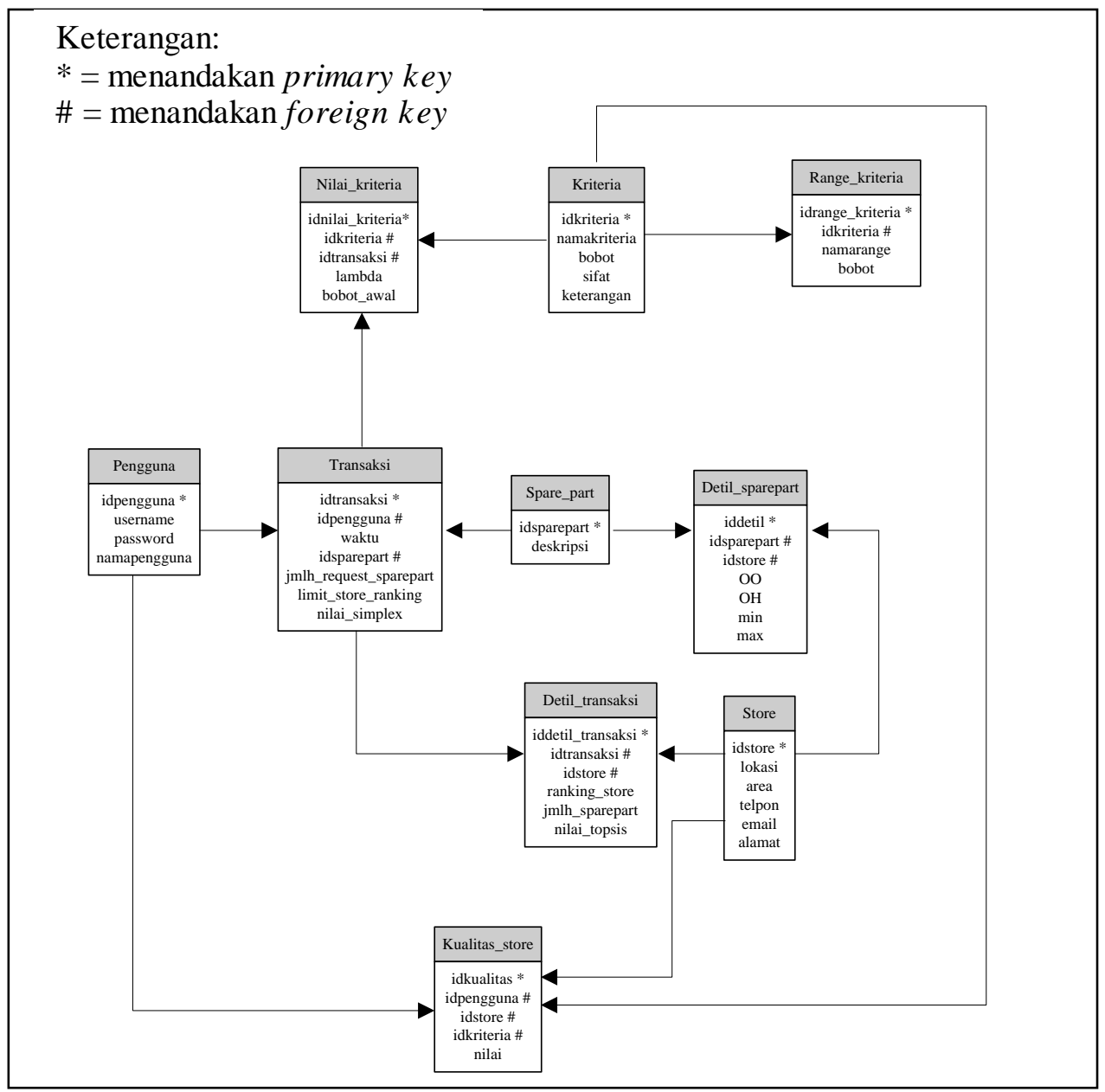

Gambar 3. Relasi antar tabel

Prosedur perhitungan metode bobot entropy adalah sebagai berikut:

a. Penormalisasian setiap elemen dari matriks evaluasi

Diawali dengan pembuatan matriks evaluasi berisi nilai data yang belum dinormalisasi berdasarkan store dan kriteria. Proses selanjutnya merupakan proses normalisasi dengan mengacu pada sifat kriteria, apakah berupa kriteria benefit atau kriteria cost. Kriteria benefit adalah kriteria dimana pengambil keputusan menginginkan nilai maksimum diantara seluruh nilai alternatif. Kriteria cost adalah kriteria dimana pengambil keputusan menginginkan nilai minimum diantara seluruh nilai alternatif.

$$
\begin{aligned}
\mathrm{EM}= & \begin{array}{ccc}
\mathrm{b}_{11} & \cdots & \mathrm{b}_{1 \mathrm{n}} \\
\vdots & \ddots & \vdots \\
b_{\mathrm{m} 1} & \cdots & \mathrm{b}_{\mathrm{mn}}
\end{array} \\
c_{\mathrm{ik}}= & \frac{\mathrm{b}_{\mathrm{ik}}}{\mathrm{b}_{\mathrm{ik} \text { maks }}} ; \text { Untuk kriteria benefit } \\
\frac{\mathrm{b}_{\mathrm{ik} \text { min }}}{\mathrm{b}_{\mathrm{ik}}} & \text { Untuk kriteria cost }
\end{aligned}
$$

Keterangan:

$\mathrm{EM}=$ matriks evaluasi

IJCCS Vol. 6, No. 1, January 2012 : $11-22$ 
$\mathrm{b}_{\mathrm{ik}} \quad=$ nilai data yang belum dinormalisasi berdasarkan store dan kriteria

$\mathrm{b}_{\mathrm{ik} \mathrm{maks}}=$ nilai data yang belum dinormalisasi dan bernilai maksimum berdasarkan store serta kriteria

$\mathrm{b}_{\mathrm{ikmin}} \quad=$ nilai data yang belum dinormalisasi dan bernilai minimum berdasarkan store serta kriteria

$\mathrm{c}_{\mathrm{ik}} \quad=$ nilai data yang telah dinormalisasi berdasarkan store dan kriteria

Tabel 2. Penilaian Manajer

\begin{tabular}{|c|c|c|c|}
\hline Kriteria & Range & Penilaian & Keterangan \\
\hline \multirow{5}{*}{ Kuantiti spare part yang dimiliki } & $\mathrm{X}<=20$ & 1 & \multirow{5}{*}{$\begin{array}{l}\text { Banyaknya } \\
\text { ketersediaan } \\
\text { spare part di } \\
\text { store }\end{array}$} \\
\hline & $20<X<=40$ & 2 & \\
\hline & $40<X<=60$ & 3 & \\
\hline & $60<X<=80$ & 4 & \\
\hline & $X>80$ & 5 & \\
\hline \multirow{5}{*}{ Tingkat komunikasi } & Sangat buruk & 1 & \multirow{5}{*}{$\begin{array}{l}\text { Bagaimana } \\
\text { jalinan } \\
\text { komunikasi } \\
\text { antar store }\end{array}$} \\
\hline & Buruk & 2 & \\
\hline & Cukup & 3 & \\
\hline & Baik & 4 & \\
\hline & Sangat baik & 5 & \\
\hline \multirow{5}{*}{ Lama pengiriman } & $X<=2$ & 5 & \multirow{5}{*}{$\begin{array}{l}\text { Jangka waktu } \\
\text { pengiriman } \\
\text { spare part } \\
\text { antar store }\end{array}$} \\
\hline & $2<X<=5$ & 4 & \\
\hline & $5<X<=7$ & 3 & \\
\hline & $7<X<=9$ & 2 & \\
\hline & $X>9$ & 1 & \\
\hline \multirow{5}{*}{ Persentase keuntungan } & $\mathrm{X}<=10 \%$ & 1 & \multirow{5}{*}{$\begin{array}{l}\text { Besarnya } \\
\text { keuntungan } \\
\text { store per bulan }\end{array}$} \\
\hline & $10 \%<X<=20 \%$ & 2 & \\
\hline & $20 \%<X<=30 \%$ & 3 & \\
\hline & $30 \%<\mathrm{X}<=40 \%$ & 4 & \\
\hline & $X>40 \%$ & 5 & \\
\hline \multirow{5}{*}{ Biaya pengiriman } & $\mathrm{X}<=200.000$ & 5 & \multirow{5}{*}{$\begin{array}{l}\text { Besarnya biaya } \\
\text { pengiriman dari } \\
\text { store asal ke } \\
\text { store tujuan }\end{array}$} \\
\hline & $200.000<X<=400.000$ & 4 & \\
\hline & $400.000<X<=600.000$ & 3 & \\
\hline & $600.000<\mathrm{X}<=800.000$ & 2 & \\
\hline & $X>800.000$ & 1 & \\
\hline
\end{tabular}

Contoh matriks evaluasi yang berisi nilai data yang belum ternormalisasi dan merupakan nilai data konversi sebagai berikut:

$$
E \begin{array}{rrrrrr}
2 & 5 & 5 & 1 & 5 \\
1 & 4 & 4 & 3 & 1 \\
4 & 5 & 2 & 2 & 5 \\
E M=\text { benefit cost cost benefit benefit }
\end{array}
$$

Selanjutnya proses normalisasi yang didasari oleh sifat kriteria. Didapat nilai maks dari kolom 1, kolom 4, kolom 5 adalah nilai 4, nilai 3, nilai 5 dan nilai minimal dari kolom 2 dan kolom 3 adalah nilai 4 , nilai 2 . Sehingga bentuk matriks ternormalisasinya adalah sebagai berikut: 


$$
\mathrm{EM}=\begin{array}{rrrrrrrrrr}
\frac{2}{4} & \frac{4}{5} & \frac{2}{5} & \frac{1}{3} & \frac{5}{5} & & & & & \\
\frac{1}{4} & \frac{4}{4} & \frac{2}{4} & \frac{3}{3} & \frac{1}{5}= & 0.25 & 1.00 & 0.50 & 1.00 & 0.20 \\
\frac{4}{4} & \frac{4}{5} & \frac{2}{2} & \frac{2}{3} & \frac{5}{5} & & & & &
\end{array}
$$

b. Perhitungan probabilitas kriteria

Tahap selanjutnya dari perhitungan metode bobot entropy adalah menghitung probabilitas kriteria. Proses perhitungan probabilitas kriteria merupakan pembagian nilai data yang ternormalisasi dengan jumlah nilai data ternormalisasi.

$$
P_{\mathrm{ik}}=\frac{c_{\mathrm{ik}}}{\mathrm{m}_{\mathrm{i}=1} c_{\mathrm{ik}}}
$$

Keterangan:

$\mathrm{P}_{\mathrm{ik}} \quad=$ probabilitas kriteria berdasarkan store dan kriteria

$\mathrm{c}_{\mathrm{ik}} \quad=$ nilai data yang telah dinormalisasi berdasarkan store dan kriteria

Dari contoh yang ada maka hasil probabilitas kriteria adalah sebagai berikut:

$$
\begin{aligned}
& \frac{0.50}{1.75} \quad \frac{0.80}{2.60} \quad \frac{0.40}{1.90} \quad \frac{0.33}{2.00} \quad \frac{1.00}{2.20} \\
& P_{\mathrm{ik}}=\frac{0.25}{1.75} \quad \frac{1.00}{2.60} \quad \frac{0.50}{1.90} \quad \frac{1.00}{2.00} \quad \frac{0.20}{2.20} \\
& \frac{1.00}{1.75} \quad \frac{0.80}{2.60} \quad \frac{1.00}{1.90} \quad \frac{0.67}{2.00} \quad \frac{1.00}{2.20}
\end{aligned}
$$

c. Pengukuran Entropy untuk setiap kriteria

Berdasarkan nilai probabilitas kriteria maka akan diukur nilai entropy terhadap setiap kriteria.

$$
\mathrm{E}_{\mathrm{k}}=-\frac{1}{\ln \mathrm{m}} \quad \mathrm{n}_{\mathrm{k}=1}^{\mathrm{n}} \mathrm{P}_{\mathrm{ik}} \ln \mathrm{P}_{\mathrm{ik}}
$$

Keterangan:

$\mathrm{E}_{\mathrm{k}} \quad=$ nilai entropy berdasarkan data ternormalisasi per kriteria

$\mathrm{P}_{\mathrm{ik}} \quad=$ probabilitas kriteria berdasarkan store dan kriteria

$\mathrm{k} \quad=1,2, . . \mathrm{n}$ merupakan sejumlah kriteria

$\mathrm{i} \quad=1,2, \ldots \mathrm{m}$ merupakan sejumlah store

Adapun nilai pengukuran Entropy untuk setiap kriteria dengan data contoh adalah sebagai berikut:

$\mathrm{E}_{\mathrm{k}}$

$=(-0.910 *-0.96)(-0.910 *-1.09) \quad(-0.910 *-1.02) \quad(-0.910 *-1.01) \quad(-0.910 *-0.93)$

d. Perhitungan Bobot Entropy

Pengambil keputusan telah memberikan bobot awal terhadap setiap kriteria. Bobot awal yang telah ditentukan sebagai kriteria, berhubungan secara langsung dengan rata-rata informasi

IJCCS Vol. 6, No. 1, January 2012: 11-22 
yang dibangkitkan dengan sekumpulan nilai entropy setiap kriteria. Perhitungan bobot entropy sebenarnya menggunakan persamaan (5) dan (6)

Pengambil keputusan memberikan penilaian bobot awal kriteria sebagai berikut:

$$
\begin{gathered}
w_{k}=0.2 \quad 0.3 \quad 0.2 \quad 0.05 \quad 0.25 \\
\mathrm{~L}_{\mathrm{k}}=\frac{1}{\mathrm{n}-\left(\sum_{\mathrm{k}=1}^{\mathrm{n}}\left(\mathrm{E}_{\mathrm{k}}\right)\right)} 1-\mathrm{E}_{\mathrm{k}}, 0 \leq \mathrm{L}_{\mathrm{k}} \leq 1 \\
\mathrm{WE} \mathrm{E}_{\mathrm{k}}=\frac{\mathrm{L}_{\mathrm{k}} * \mathrm{w}_{\mathrm{k}}}{\frac{\mathrm{n}}{\mathrm{k}=1} \mathrm{~L}_{\mathrm{k}} * w_{\mathrm{k}}}
\end{gathered}
$$

Keterangan:

$\mathrm{E}_{\mathrm{k}} \quad=$ nilai entropy berdasarkan data ternormalisasi per kriteria

$\mathrm{L}_{\mathrm{k}} \quad=$ lamda per kriteria dimana nilainya berada pada range 0 hingga 1

$\mathrm{w}_{\mathrm{k}} \quad=$ bobot awal yang telah ditentukan sebelumnya oleh pengambil keputusan

$\mathrm{WE}_{\mathrm{k}} \quad=$ bobot entropy sebenarnya untuk tiap kriteria

Hasil perhitungan bobot entropy sebenarnya dengan data contoh dapat dilihat sebagai berikut:

$$
\begin{aligned}
& \mathrm{WE}_{\mathrm{k}}=\frac{0.03 * 0.2}{0.191} \quad \frac{0.01 * 0.3}{0.191} \quad \frac{0.17 * 0.2}{0.191} \quad \frac{0.18 * 0.05}{0.191} \quad \frac{0.34 * 0.25}{0.191}
\end{aligned}
$$

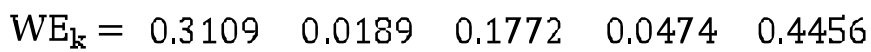

Setelah mendapatkan penilaian bobot kriteria dari perhitungan metode Entropy, maka langkah selanjutnya adalah melakukan proses perankingan dengan metode TOPSIS.

Prosedur perhitungan metode TOPSIS adalah sebagai berikut:

a. Membuat matriks keputusan yang ternormalisasi

TOPSIS membutuhkan rating kinerja setiap alternatif pada setiap kriteria yang ternormalisasi. Rating kinerja tersebut melalui proses normalisasi, agar terjadi kesamaan skala pengukuran terhadap sejumlah indikator (nilai masukan yang diinisialisasi pada matriks berada pada skala 0 hingga 1 ).

$$
r_{i k}=\frac{b_{i k}}{m_{i=1}^{m} b_{i k}^{2}}
$$

Keterangan:

$\mathrm{r}_{\mathrm{ik}} \quad=$ nilai data ternormalisasi berdasarkan tiap kriteria dari tiap store

$\mathrm{b}_{\mathrm{ik}} \quad=$ nilai data yang belum dinormalisasi berdasarkan store dan kriteria

$$
\begin{array}{rcccc}
\frac{2}{4.58} & \frac{5}{8.12} & \frac{5}{6.71} & \frac{1}{3.74} & \frac{5}{7.14} \\
\mathrm{r}=\frac{1}{1.75} & \frac{4}{2.60} & \frac{4}{1.90} & \frac{3}{2.00} & \frac{1}{2.20} \\
\frac{4}{1.75} & \frac{5}{2.60} & \frac{2}{1.90} & \frac{2}{2.00} & \frac{5}{2.20}
\end{array}
$$

b. Membuat matriks keputusan yang ternormalisasi terbobot (V)

Matriks keputusan ternormalisasi terbobot $(\mathrm{V})$ dihitung dengan mengalikan nilai pada tiap alternatif di matriks ternormalisasi $\left(\mathrm{r}_{\mathrm{ij}}\right)$ dengan bobot masing-masing kriteria $\left(\mathrm{WE}_{\mathrm{k}}\right)$ yang telah didapat dari hasil perhitungan metode Entropy. 


$$
\mathrm{V}=\begin{array}{cccc}
W E_{1} r_{11} & W E_{2} r_{12} & \ldots & W E_{n} r_{1 n} \\
\vdots & \vdots & & \vdots \\
W E_{1} r_{m 1} & W E_{2} r_{m 2} & \ldots & W E_{n} r_{m n}
\end{array}
$$

Keterangan:

$\mathrm{V}=$ matriks ternormalisasi terbobot

$W E_{\mathrm{k}}=$ bobot entropy sebenarnya untuk tiap kriteria

$\mathrm{r}_{\mathrm{ik}} \quad=$ nilai data ternormalisasi berdasarkan tiap kriteria dari tiap store

Berdasarkan data contoh maka matriks keputusan ternormalisasi terbobot adalah sebagai berikut:

$$
\begin{aligned}
& \text { V } \\
& 0.44 * 0.3109 \quad 0.62 * 0.0189 \quad 0.75 * 0.1772 \quad 0.27 * 0.0474 \quad 0.70 * 0.4456 \\
& =0.22 * 0.3109 \quad 0.49 * 0.0189 \quad 0.60 * 0.1772 \quad 0.80 * 0.0474 \quad 0.14 * 0.4456 \\
& 0.87 * 0.3109 \quad 0.62 * 0.0189 \quad 0.30 * 0.1772 \quad 0.53 * 0.0474 \quad 0.70 * 0.4456
\end{aligned}
$$

c. Menentukan matriks solusi ideal positif dan matriks solusi ideal negatif

Penentuan solusi ideal positif $\left(\mathrm{S}_{\mathrm{k}}^{+}\right)$dan solusi ideal negatif $\left(\mathrm{S}_{\mathrm{k}}{ }^{-}\right)$diperoleh berdasarkan sifat atribut kriteria.

$$
\begin{gathered}
\mathrm{S}_{\mathrm{k}}^{+}=\underset{\mathrm{maks}_{\mathrm{j}} \mathrm{V}_{\mathrm{jk}}, j \mathrm{ikak} \text { adalah atribut keuntungan }}{\min _{\mathrm{j}} \mathrm{V}_{\mathrm{jk}}, j \mathrm{ikak} \text { adalah atribut biaya }}=\mathrm{V}_{1}^{+}, \mathrm{V}_{2}^{+}, \ldots \mathrm{V}_{\mathrm{n}}^{+} \\
\mathrm{S}_{\mathrm{k}}^{-}=\underset{\min _{\mathrm{j}} \mathrm{V}_{\mathrm{jk}}, j \mathrm{ikak} \text { adalah atribut keuntungan }}{\operatorname{maks}_{\mathrm{j}} \mathrm{V}_{\mathrm{jk}}, j \text { ikak adalah atribut biaya }}=\left(\mathrm{V}_{1}^{-}, \mathrm{V}_{2}^{-}, \ldots \mathrm{V}_{\mathrm{n}}^{-}\right)
\end{gathered}
$$

Solusi ideal positif dan solusi ideal negatif dari data contoh adalah sebagai berikut:

$\mathrm{S}_{1}{ }^{+}=$nilai maksimal 0.2714 karena kriteria 1 merupakan atribut keuntungan

$\mathrm{S}_{2}{ }^{+}=$nilai minimal 0.0093 karena kriteria 2 merupakan atribut biaya

$\mathrm{S}_{3}{ }^{+}=$nilai minimal 0.0528 karena kriteria 3 merupakan atribut biaya

$\mathrm{S}_{4}^{+}=$nilai maksimal 0.0380 karena kriteria 4 merupakan atribut keuntungan

$\mathrm{S}_{5}^{+}=$nilai maksimal 0.3120 karena kriteria 5 merupakan atribut keuntungan

$\mathrm{S}_{1}{ }^{-}=$nilai minimal 0.0678 karena kriteria 1 merupakan atribut keuntungan

$\mathrm{S}_{2}{ }^{-}=$nilai maksimal 0.0116 karena kriteria 2 merupakan atribut biaya

$\mathrm{S}_{3}{ }^{-}=$nilai maksimal 0.1321 karena kriteria 3 merupakan atribut biaya

$\mathrm{S}_{4}{ }^{-}=$nilai minimal 0.0217 karena kriteria 4 merupakan atribut keuntungan

$\mathrm{S}_{5}{ }^{-}=$nilai minimal 0.0624 karena kriteria 5 merupakan atribut keuntungan

d. Menentukan jarak antara nilai setiap alternatif dengan matriks solusi ideal positif dan matriks solusi ideal negatif

$$
\begin{aligned}
& D_{\mathrm{j}}^{+}=\overline{\frac{\mathrm{n}}{\mathrm{k}=1} \mathrm{~S}_{\mathrm{k}}^{+}-\mathrm{S}_{\mathrm{ik}}{ }^{2}} \\
& \mathrm{D}_{\mathrm{j}}^{-}=\overline{\frac{\mathrm{n}=1}{\mathrm{n}=1}\left(\mathrm{~S}_{\mathrm{jk}}-\mathrm{S}_{\mathrm{k}}^{-}\right)^{2}}
\end{aligned}
$$

Jarak antara nilai setiap alternatif dengan solusi ideal positif data contoh adalah sebagai berikut:

IJCCS Vol. 6, No. 1, January 2012 : $11-22$ 


$\begin{array}{rllll}0.018414 & 0.000005 & 0.006280 & 0.000643 & 0.000000 \\ \mathrm{D}_{\mathrm{j}}^{+}=0.041432 & 0.000000 & 0.002791 & 0.000000 & 0.062286 \\ 0.00000 & 0.000005 & 0.000000 & 0.000161 & 0.000000\end{array}$

Jarak antara nilai setiap alternatif dengan solusi ideal negatif data contoh adalah sebagai berikut:

$\begin{array}{rllll}0.004604 & 0.000000 & 0.000000 & 0.000000 & 0.062286 \\ \mathrm{D}_{\mathrm{j}}^{-}=0.000000 & 0.000005 & 0.000698 & 0.000643 & 0.000000 \\ 0.041432 & 0.000000 & 0.006280 & 0.000161 & 0.062286\end{array}$

e. Menentukan nilai preferensi untuk setiap alternatif.

Akhirnya, prosedur metode TOPSIS adalah mencari nilai preferensi untuk setiap alternatif. Nilai preferensi untuk setiap alternatif, ditunjukkan pada persamaan (13), dimana nilai preferensi (T) yang lebih besar menunjukkan bahwa alternatif tersebut lebih dipilih.

$$
\mathrm{T}=\frac{\mathrm{D}_{\mathrm{i}}^{-}}{\mathrm{D}_{\mathrm{i}}^{-}+\mathrm{D}_{\mathrm{i}}^{+}}
$$

Keterangan:

$\mathrm{T}=$ nilai preferensi untuk setiap alternatif store

$\mathrm{D}_{\mathrm{j}}^{-} \quad=$ jarak setiap alternatif dari solusi ideal negatif

$\mathrm{D}_{\mathrm{j}}^{+} \quad=$ jarak setiap alternatif dari solusi ideal positif

Hasil perhitungan nilai preferensi untuk setiap alternatif dengan data contoh adalah $\mathrm{T} 3>\mathrm{T} 1>$ T2. Hal ini menunjukkan alternatif 3 merupakan alternatif yang terbaik dari sejumlah alternatif yang ada.

$$
T=\frac{0.258630}{0.258630+0.159192}=0.62
$$

Tahapan selanjutnya adalah proses pengalokasian spare part dengan menggunakan pendekatan matematis goal programming. Adapun bentuk umum goal programming, ditunjukkan pada persamaan (14)

$$
\begin{array}{ll}
\text { Fungsi Objektif: } & =\mathrm{P}_{1} \mathrm{~d}_{1}{ }^{-}+\ldots+\mathrm{P}_{\mathrm{i}} \mathrm{d}_{\mathrm{i}}^{+} \\
\text {Fungsi batasan: } & \\
& \\
& \mathrm{a}_{1} \mathrm{X}_{1}+\ldots \mathrm{a}_{\mathrm{m}} \mathrm{X}_{\mathrm{n}}+\mathrm{d}_{1}^{-}{ }^{-} \mathrm{d}_{1}{ }^{+}=\mathrm{bs}_{1} \\
& \mathrm{a}_{2} \mathrm{X}_{1}+\ldots \mathrm{a}_{\mathrm{m}} \mathrm{X}_{\mathrm{n}}+\mathrm{d}_{2}{ }^{-}-\mathrm{d}_{2}{ }^{+}=\mathrm{bs}_{2} \\
& \ldots \ldots \ldots \ldots \ldots \ldots \ldots \ldots . \\
& \mathrm{a}_{\mathrm{m}} \mathrm{X}_{1}+\ldots \mathrm{a}_{\mathrm{m}} \mathrm{X}_{\mathrm{n}}+\mathrm{d}_{\mathrm{i}}{ }^{-}-\mathrm{d}_{\mathrm{i}}{ }^{+}=\mathrm{bs}_{\mathrm{m}} \\
& \mathrm{X}_{1}, \mathrm{X}_{2} \ldots \mathrm{X}_{\mathrm{n}}, \mathrm{d}_{\mathrm{i}}{ }^{-}, \mathrm{d}_{\mathrm{i}}{ }^{+} \geq 0
\end{array}
$$


Keterangan:

$\begin{array}{ll}\mathrm{X}_{1}, \mathrm{X}_{2} . . \mathrm{X}_{\mathrm{n}} & =\text { alternatif keputusan } \\ \mathrm{P}_{1}, \mathrm{P}_{2} . . \mathrm{P}_{\mathrm{i}} & =\text { prioritas } \\ \mathrm{a}_{1}, \mathrm{a}_{2}, . . \mathrm{a}_{\mathrm{m}} & =\text { menyajikan sumber daya } \\ \mathrm{bs}_{1}, \mathrm{bs}_{2}, . . \mathrm{bs}_{\mathrm{m}} & =\text { batasan sumber daya } \\ \mathrm{d}_{1}{ }^{-}, \mathrm{d}_{2}{ }^{-}, . . \mathrm{d}_{\mathrm{i}}^{-} & =\text {variabel penyimpangan negatif } \\ \mathrm{d}_{1}{ }^{+}, \mathrm{d}_{2}{ }^{+}, . . \mathrm{d}_{\mathrm{i}}^{+} & =\text {variabel penyimpangan positif }\end{array}$

Beberapa tujuan ditetapkan antara lain: tepat memenuhi kebutuhan spare part pertama, memenuhi kebutuhan spare part kedua, memenuhi budget biaya pengiriman, tidak melebihi sumber daya spare part pertama dari masing-masing store, tidak melebihi kapasitas yang telah ditetapkan oleh store, tidak melebihi sumber daya spare part kedua dari masing-masing store. Bentuk matematisnya ditunjukkan pada persamaan (16). Nilai-nilai disebelah kanan persamaan merupakan nilai-nilai sumber daya store misalnya kapasitas spare part store yang dapat didistribusikan, biaya per item spare part, kebutuhan banyaknya spare part yang diinginkan. Jika variabel tersebut memiliki hubungan dengan sistem maka koefisien variabelnya diberi nilai 1.

Fungsi Objektif: Min

Fungsi batasan :

(Kebutuhan spare part pertama)

(Kebutuhan spare part kedua)

(budget biaya pengiriman)

(store pertama spare part1)

(store kedua spare part1)

(store ketiga spare part1)

(kapasitas store pertama)

(kapasitas store kedua)

(kapasitas store ketiga)

(store pertama spare part2)

(store kedua spare part2)

(store ketiga spare part2)

$$
\begin{aligned}
& =\mathrm{P}_{1} \mathrm{~d}_{1}{ }^{-}+\mathrm{P}_{1} \mathrm{~d}_{1}{ }^{+}+\mathrm{P}_{2} \mathrm{~d}_{2}{ }^{-}+\mathrm{P}_{2} \mathrm{~d}_{2}{ }^{+}+\mathrm{P}_{3} \mathrm{~d}_{3}{ }^{+}+\mathrm{P}_{4} \mathrm{~d}_{4}{ }^{+}+\mathrm{P}_{5} \mathrm{~d}_{5}{ }^{+}+\mathrm{P}_{6} \mathrm{~d}_{6}{ }^{+} \\
& X_{1}+X_{2}+X_{3}+d_{1}^{-}-d_{1}{ }^{+}=70 \\
& \mathrm{X}_{4}+\mathrm{X}_{5}+\mathrm{X}_{6}+\mathrm{d}_{2}{ }^{-}-\mathrm{d}_{2}{ }^{+}=60 \\
& 3 X_{1}+5 X_{2}+4 X_{3}+d_{3}^{-}-d_{3}{ }^{+}=500 \\
& \mathrm{X}_{1}+\mathrm{d}_{4}{ }^{-}-\mathrm{d}_{4}{ }^{+}=62 \\
& \mathrm{X}_{2}+\mathrm{d}_{4}{ }^{-}-\mathrm{d}_{4}{ }^{+}=1 \\
& \mathrm{X}_{3}+\mathrm{d}_{4}{ }^{-}-\mathrm{d}_{4}{ }^{+}=9 \\
& \mathrm{X}_{1}+\mathrm{X}_{4}+\mathrm{d}_{5}{ }^{-}-\mathrm{d}_{5}{ }^{+}=100 \\
& \mathrm{X}_{2}+\mathrm{X}_{5}+\mathrm{d}_{5}{ }^{-}-\mathrm{d}_{5}{ }^{+}=150 \\
& \mathrm{X}_{3}+\mathrm{X}_{6}+\mathrm{d}_{5}^{-}-\mathrm{d}_{5}^{+}=100 \\
& \mathrm{X}_{4}+\mathrm{d}_{6}{ }^{-}-\mathrm{d}_{6}{ }^{+}=3 \\
& \mathrm{X}_{5}+\mathrm{d}_{6}{ }^{-}-\mathrm{d}_{6}{ }^{+}=1 \\
& \mathrm{X}_{6}+\mathrm{d}_{6}{ }^{-}-\mathrm{d}_{6}{ }^{+}=35 \\
& \mathrm{X}_{1}, \mathrm{X}_{2} \ldots \mathrm{X}_{\mathrm{n}}, \mathrm{d}_{\mathrm{i}}^{-}, \mathrm{d}_{\mathrm{i}}^{+} \geq 0
\end{aligned}
$$

\section{HASIL DAN PEMBAHASAN}

Pengambil keputusan memberikan inputan kepada sistem berupa pemilihan banyaknya item spare part yang dibutuhkan, pemilihan kode spare part yang dibutuhkan, memasukan banyaknya spare part yang dibutuhkan untuk didistribusi, memasukan banyaknya store yang akan diranking berdasarkan data kriteria yang ada, besarnya budget biaya pengiriman. Hasil penelitian menunjukkan bahwa sifat dari tiap kriteria (benefit atau cost) berpengaruh pada hasil matrik solusi ideal. Jika hasil jarak alternatif terhadap solusi ideal positif makin besar, maka nilai preferensi tiap store spare part makin kecil. Semakin besar nilai total preferensi store spare part maka semakin tinggi ranking store spare part tersebut. Tujuan prioritas telah terpenuhi jika variabel penyimpangan positif dan variabel penyimpangan negatif bernilai 0 .

IJCCS Vol. 6, No. 1, January 2012: 11-22 


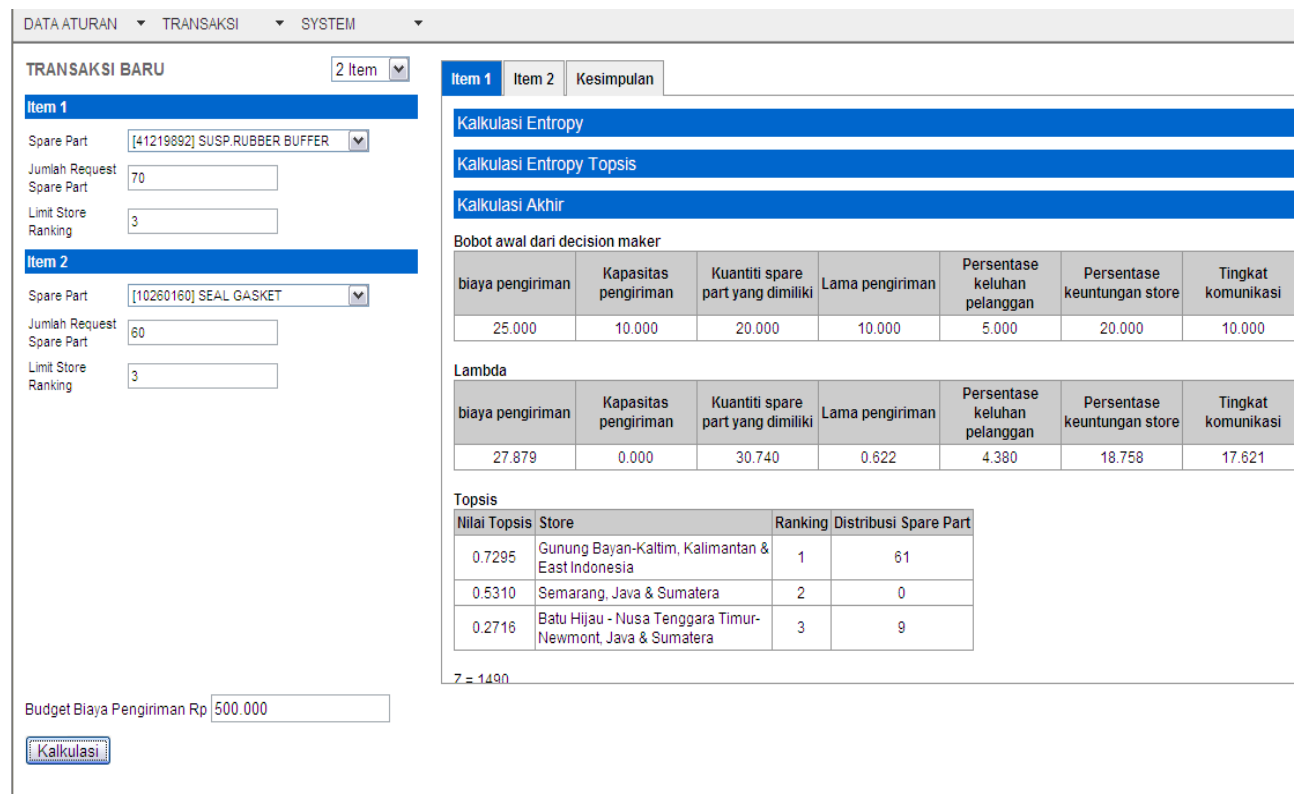

Gambar 4. Inputan sistem

\begin{tabular}{l|l|l|c}
\hline & & & Ranking \\
\hline [v1] & 0.619 & Semarang, Java \& Sumatera & 2 \\
\hline [V2] & 0.101 & $\begin{array}{l}\text { Batu Hijau - Nusa Tenggara Timur- } \\
\text { Newmont, Java \& Sumatera }\end{array}$ & 3 \\
\hline [V3] & 0.963 & $\begin{array}{l}\text { Gunung Bayan-Kaltim, Kalimantan \& } \\
\text { East Indonesia }\end{array}$ & 1 \\
\hline
\end{tabular}

Gambar 5. Hasil perankingan

\section{KESIMPULAN}

- Hasil yang diperoleh dari sistem adalah menampilkan nilai perankingan store spare part dengan metode TOPSIS secara urut menurun, dan menampilkan kapasitas pendistribusian spare part berdasarkan ranking store tersebut dalam bentuk tabel.

- Sifat dari tiap kriteria (benefit atau cost). Sifat benefit kriteria maupun cost kriteria akan berpengaruh pada hasil matrik solusi ideal untuk mendapatkan hasil jarak alternatif tiap store spare part. Jika hasil jarak alternatif terhadap solusi ideal positif makin besar, maka nilai preferensi tiap store spare part makin kecil

- Variabel penyimpangan. Variabel penyimpangan positif $(\mathrm{d}+)$ dan variabel penyimpangan negatif (d-) bernilai 0 , menunjukkan bahwa tujuan berprioritas telah dipenuhi

\section{SARAN}

Sistem pendukung keputusan yang dibangun memfokuskan pada perankingan store spare part serta alokasi pendistribusian spare part dengan metode Entropy-TOPSIS-Goal Programming, penelitian selanjutnya dapat mengembangkan prosedur alokasi pendistribusian dan prosedur perankingan dengan metode lain. Hasil keluaran sistem hanya merupakan sarana pendukung untuk dapat membantu pihak manajerial dalam memberikan rekomendasi. 


\section{DAFTAR PUSTAKA}

[1] Turban, E., Sharda, R., dan Delen, D., 2011, Decision Support And Business Intelligence Systems, Ninth Edition, Pearson New Jersey.

[2] Pirdashti, M., Ghadi, A., Mohammadi, M., dan Shojatalab, G., 2009, Multi Criteria Decision Making Selection Model with Application to Chemical Engineering Management Decisions, World Academy of Science, Engineering And Technology 49

[3] Shannon, C.E, 1948, A Mathematical Theory of Communication, The Bell System Technical Journal vol. 27 p379-423, p623-656

[4] Hsu, P., dan Hsu, M., 2008, Optimizing The Information Outsourcing Practices of Primary Care Medical Organizations Using Entropy and TOPSIS, Springer Quality Quantity, hal.181- 201

[5] Triyanti, V., dan Gadis, M.T., 2008, Pemilihan Supplier untuk Industri Makanan menggunakan Metode Promethee, Journal of Logistics and Supply Chain Management Vol.1 No.2 hal 83-92, Jakarta

[6] Lawrence, J., dan Pasternack, B., 2002, Applied Management Science, Second Edition, John Wiley\&Sons, New York

[7] Render, B., Stair, R., dan Hanna, M.E., 2003, Quantitative Analysis for Management, Eight Edition, Prentice Hall, New Jersey

[8] Cheng, S.K., dan Saskatchewan, R., 2000, Development of a Fuzzy Multi-Criteria Decision Support System for Municipal Solid Waste Management, Thesis, Master of Applied Science in Advanced Manufacturing and Production Systems University of Regina, Canada

IJCCS Vol. 6, No. 1, January 2012 : $11-22$ 